\title{
"Dynamics in futures and spot markets: A panel study of advanced and emerging economies of Asia"
}

\begin{tabular}{|c|c|}
\hline AUTHORS & $\begin{array}{l}\text { Sangeeta Wats (iD) } \\
\text { Chandrima Sikdar (D) }\end{array}$ \\
\hline ARTICLE INFO & $\begin{array}{l}\text { Sangeeta Wats and Chandrima Sikdar (2022). Dynamics in futures and spot } \\
\text { markets: A panel study of advanced and emerging economies of Asia. } \\
\text { Investment Management and Financial Innovations, 19(1), 64-76. } \\
\text { doi:10.21511/imfi.19(1).2022.05 }\end{array}$ \\
\hline DOI & http://dx.doi.org/10.21511/imfi.19(1).2022.05 \\
\hline RELEASED ON & Wednesday, 02 February 2022 \\
\hline RECEIVED ON & Friday, 04 June 2021 \\
\hline ACCEPTED ON & Friday, 21 January 2022 \\
\hline LICENSE & $\begin{array}{l}(c) \text { EY } \\
\text { This work is licensed under a Creative Commons Attribution } 4.0 \text { International } \\
\text { License }\end{array}$ \\
\hline JOURNAL & "Investment Management and Financial Innovations" \\
\hline ISSN PRINT & $1810-4967$ \\
\hline ISSN ONLINE & $1812-9358$ \\
\hline PUBLISHER & LLC "Consulting Publishing Company "Business Perspectives" \\
\hline FOUNDER & LLC "Consulting Publishing Company "Business Perspectives" \\
\hline
\end{tabular}

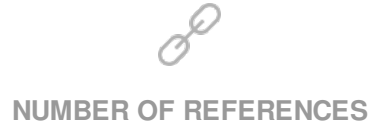

50

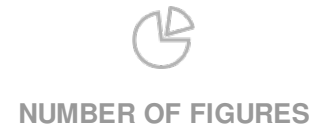

0
NUMBER OF TABLES

7

(C) The author(s) 2022. This publication is an open access article. 


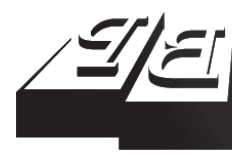

\section{BUSINESS PERSPECTIVES}

()

LLC "CPC "Business Perspectives" Hryhorii Skovoroda lane, 10, Sumy, 40022, Ukraine www.businessperspectives.org
Received on: $4^{\text {th }}$ of June, 2021 Accepted on: $21^{\text {st }}$ of January, 2022 Published on: $2^{\text {nd }}$ of February, 2022

(C) Sangeeta Wats, Chandrima Sikdar, 2022

Sangeeta Wats, Ph.D., Associate Professor, School of Business Management, Narsee Monjee Institute of Management Studies University (NMIMS University), India. Corresponding author)

Chandrima Sikdar, Ph.D., Professor, School of Business Management, Narsee Monjee Institute of Management Studies University (NMIMS University), India.

\title{
DYNAMICS IN FUTURES AND SPOT MARKETS: A PANEL STUDY OF ADVANCED AND EMERGING ECONOMIES OF ASIA
}

\begin{abstract}
The study explores the underpinning interlinkages in the spot and futures markets across nine Asian advanced and emerging economies, and examines whether development status has any impact on the nature and speed of adjustments in the information transmission. By applying Panel VECM to the data set from the very day futures trading was initiated on the respective exchange till February 2020, the results highlight that in the long run, over the entire period, the futures market adjusts $69.7 \%$ more than the spot market and there is a bidirectional causality in the short run. Even in the sub-periods, the same phenomena were observed, and in the short run, there was a unidirectional causality from futures to spot during the crisis period. An identical trend was observed for country groups in three sub-periods. However, in the short run, during the crisis period, a unidirectional causality from futures to spot was found in advanced economies, while the opposite pattern was found in emerging economies. The paper establishes that the spot market dominates the information dissemination process. The results also demonstrate that traders prefer liquidity over leverage as their trading venue, the existence of potential index arbitrage opportunities, and validate that development status has no impact on the information transmission pattern amongst the markets, except during turbulent times. The study offers insights to market participants to develop their specific trading strategies in these markets at various economic stages, thereby increasing their expected returns.
\end{abstract}

Keywords

JEL Classification

\section{INTRODUCTION}

The dilemma as to which market, futures or spot, should be considered to develop trading strategies remains a matter of interest and concern among researchers, portfolio managers and academicians. Derivatives were instituted to ensure a hedging mechanism and price discovery process. Ideally, there should be consistent price co-movement in the derivatives market and its underlying spot market, leading to zero arbitrage opportunity. However, several studies demonstrate that futures market supersedes the spot market owing to its market microstructure, resulting in arbitrage. Hence, traders may choose the futures market having the leverage advantage to augment their estimated returns, or traders with capital constraints may exercise them as low-margin assets to reserve the effectiveness of trading funds. If market participants exhibit such an inclination, it will lead to significant divergence in their co-movement resulting in spot market making adjustments. Contrary to these aspects, numerous empirical studies establish that the futures market makes adjustments to reach equilibrium. The extent of price divergence in these markets may vary 
depending on the economy, the nature of financial markets and the extent of regulatory intervention, which eventually leads to a specific trading approach by market participants.

Against this backdrop, the key point is to empirically explore the inherent interrelatedness in the spot and futures markets.

\section{LITERATURE REVIEW}

Research on information dissemination in the futures and its underlying spot market grew significantly after the collapse of the Bretton Woods System across geographies, asset classes and different time horizons. Information transmission hinges on whether new information assimilates primarily in spot or futures prices. Efficient market theory posits that new information should be instantaneously reflected across markets resulting in no lagged responses and zero arbitrage profit. However, Fleming et al. (1996) advocate that the market that provides higher liquidity and low trading costs is likely to play a major role in information share. According to Zou and Pinfold (2001), if informed traders have economic inducements to use one market over the other, price discovery in these two markets is expected to emerge. Telser (1981) infers that futures markets might be deliberated as an impartial forecast of the successive spot prices.

Kawaller et al. (1987), Chan (1992), Hasbrouck (1995), Fleming et al. (1996), Hasbrouck (2003), and Pizzi et al. (1998) examine US equity markets and conclude that information transmission is primarily from the futures to spot market. In international equity markets, Lihara et al. (1996), Jong et al. (1998), Booth et al. (1999), Ahn et al. (2018), and Fassas and Siriopoulos (2019) infer the predominance of futures in the information share. Min and Najand (1999) examine the Korean market and confirm that futures lead the spot market. Turkington and Walsh (1999) examine the Australian market and observe a bidirectional causality between the markets. Roope and Zurbruegg (2002) studied the Singaporean and Taiwanese exchanges and established that Singaporean index futures contribute more than the Taiwanese futures exchange. Chuang (2003) investigates the Taiwan Stock Exchange Capitalization Weighted Index Futures (TAISEX) and Morgan Stanley Capital International Taiwan Index Futures
(MSCI) and ascertains a strong bilateral causality in these markets. Zhong et al. (2004) conclude that Mexican futures markets assimilate information at a rapid pace.

Wats and Misra (2008) explore the NSE Futures and its underlying from June 12, 2000 to December 31, 2007 and twenty-four Nifty stock futures and its underlying from November 9, 2001, which continuously traded until December 31, 2007. Variance decomposition analysis confirms that most of the forecast error variance in the futures and spot markets is attributed to futures market. Even the Hasbrouck information share predicates that over $90 \%$ of the average information share emanates from the futures market. Schlusche (2009) inspects Index future and Exchange Traded Funds of DAX, a German based blue chip index. Considering only the transaction data from electronic trading markets and applying linear Vector Error Correction Model, he validates that futures are the price leaders and its effect is three times more than that of ETF. Choy and Zhang (2010) and Chen and Tsai (2017) observe that in both Hong Kong regular and mini and VIX futures markets, the futures market leads the spot. Theissen (2012) applies the Hasbrouck information share and common factor weights on DAX, and discerns that the futures market leads the spot. The study infers that futures price lead is more prominent in the presence of arbitrage. It concludes that when the variation among the futures and spot markets is high, the later tends to adjust to futures market. Lin et al. (2018) observe that futures dominate the spot in the US ETFs, although the impact weakens in higher sentiment phases as informed traders have lesser inclination in leveraging their information edge in the futures market.

The study by Brandt et al. (2007) on US treasury markets deduces that financing rates and liquidity levels influence the magnitude and direction of price discovery. They confirm that Repo special- 
ness results in price discovery to originate in the futures as transacting in spot is extremely high. Kavussanos and Nomikos (2003) analyze the freight futures and spot market, BIFFEX and BPI. They document that futures prices tend to ascertain information faster than spot prices. Cheung and Fung (1997) explore the arrangement of information flow amongst the Eurodollar spot and futures markets and infer a bidirectional causality between these markets. Entrop et al. (2020) examine if market quality, uncertainty, investor sentiment and attention, and macroeconomic news impact bitcoin's informational content in the futures and spot markets. Considering a data set of December 2017 to March 2019, they infer that excessive information-based bitcoin opinion augments the informational role of futures markets. Shrestha (2014) investigates the energy markets and conclude that futures dominate the price discovery process. Shrestha et al. (2020) examine seven agricultural commodities and conclude that except for cocoa, futures reacts faster to new information. The researchers have attributed information dissemination from futures and transmitted to the underlying cash market predominantly owing to its market microstructure like leverage effect, liquidity, lower cost of transactions, availability of short positions, quick executions and lower cost of information.

Thus, the preceding paragraphs illustrate copious studies, identifying the leading role of the future markets. However, there are several studies like Quan (1992), Wahab and Lashgari (1993), Silvapulle and Moosa (1999), Chan and Lien (2002), Rajput et al. (2012), Kumar and Chaturvedula (2013), Dimpfl et al. (2017), and Karabiyik et al. (2018) that ascertain that the cash market serves as a dominant market, and futures behave like a satellite market. Jacobs (2016) exhibits that the future price may deviate from the spot price in the price discovery process, signifying the presence of mispricing.

Although there exists extensive literature on information transmission pattern between futures and spot markets covering various asset classes, geographies and different times horizons, still the results are inconclusive and debatable. Hence, the importance of another latest study involving a particular asset across a select geography involv- ing a more extended time period may hardly be overstated in view of the ever-evolving nature of the information dynamics in these markets. The purpose of this study is, first of all, to inspect the process of information transmission in the spot and futures markets over a period of time and sub-periods across developed and emerging economies in Asia. Thus, establishing which market should ideally be considered as a reference point by global asset allocators to devise their informed strategies to attain their respective objectives like hedging and profiting. It further examines whether there is any shift in the investor structure during the sub-periods and explores whether there is any variation in the information transmission pattern in the developed and emerging economies.

\section{METHODOLOGY}

The data considered in this study covers nine major stock indices of nine countries such as China, Hong Kong, India, Japan, Malaysia, Singapore, South Korea, Taiwan, and Thailand. These countries fall into two categories of advanced and emerging and developing economies based on the IMF's World Economic Outlook database classification as shown in Table A1 (Appendix). Japan designated as an advanced nation in Asia was the first country to introduce futures trading. Their markets are very dynamic and actively traded, as they are open even during nights, thereby offering more opportunities to local and international traders to adjust to their positions in response to varied instantaneous information. Singapore has evolved from an emerging country to an advance state over a period. Its financial markets are considered incredibly advance in terms of infrastructure and product offerings, and this favorable trading environment has led to increased financial institution participation. India and China are both coined as emerging economies, however, the economic set up in both countries differs in many ways, as do their financial markets. While Indian derivatives markets are older, more inclusive, market oriented and have the mature ecosystem, that of China is relatively new and is further liberalizing. These varied and specific attributes across economies, market structure, regulatory intervention, and regulatory barriers may lead to heterogeneity between the spot and future prices 
movement, subsequently leading to divergence in the co-movements of the markets and in the nature and speed of adjustments in these markets over different time periods.

To primarily estimate the impact of country-level heterogeneity on market behavior, only the major indices of those countries where futures have been traded for almost more than a decade are examined. The longer duration is likely to illustrate more reliable results as the markets have improved predominantly owing to policy changes, market infrastructure, increased investors awareness, higher financial literacy and financial inclusion, eventually leading to greater market participation and higher market depth. Further, the study also captures whether development status has any bearing on the co-movements of these markets.

The study considers a sample size comprising of daily closing prices of spot and near month index futures of the nine indices in each of the nine countries ranging from $05 / 09 / 1988$ to $28 / 02 / 2020$. The study period is from the very day futures trading started in each of these nine indices. Thus, the data considered for the study is an unbalanced panel data consisting of 59,088 observations. To emphasize the likely alterations in the dynamics of the markets and the likely trends over time with respect to the Global Final Crisis (GFC), the analysis is done for the entire period chosen and for three sub-periods within this time period. For this study, the segregation of the sub-periods predominantly emulates (Newell (2010). The literature normally posits that the estimated beginning date of GFC was around July and September 2007, and the crisis continued until October 2009. The choice of the indices and the time period considered are based on the following:

1. The focus of the study is Asia, the fastest growing region of the world.

2. The interest of the study is in examining and comparing the difference in the dynamic relationship between spot and futures prices from the very day the futures trading started on that exchange until February 28, 2020, thereby negating the impact of the global pandemic, which became more pronounced globally and swept the world from March, 2020.
3. A sub-period from the very day the futures started trading on that respective exchange to August 9, 2007 (pre-Global Financial Crisis), the second sub-period from August 10, 2007 to November 31, 2009 (the GFC period), and the third duration, post GFC, which extends from December 1, 2009 to February 28, 2020, are undertaken. The third sub-period is of huge relevance as several regulatory reforms were taken by the regulatory bodies taking cognizance of the loopholes in terms of information disclosure, risk containment, technological upgradation, increased trading hours, which happened in the Indian context, increased financial literacy and financial inclusion, giving a new dimension to the markets and the trading process.

The data on prices are in US dollars and are obtained from Bloomberg. For this study, the logarithmic transformation of prices is considered in the econometric analysis. The first differences of the logarithmic transformation of the prices may be interpreted as market returns (Nicolau \& Palomba, 2015).

An ideal theoretical no-arbitrage condition between the spot and futures markets should drive investment decisions and should be tying up both of the markets in the long run. Since both of these markets price stocks, they must both represent equal valuation or equal price of the stocks while being in equilibrium. However, in the short run, there could be factors other than price that may affect these markets, and these factors may to some extent disrupt the co-movement between the spot and futures prices (Palladini \& Portes, 2011). Also, all information relevant to pricing of stocks may not be entirely revealed in the short-run price dynamics in these markets, which advocates the existence of market inefficiency.

Thus, this study examines the dynamic relationship between these markets and employs a panel vector error correction model (VECM). A VECM allows for testing both short-run and long-run causality. In the presence of one or more cointegrating vectors in a set of variables, VECM is the most efficient estimation technique as it adapts to short-run variations in parameters and their digressions from long-run equilibrium while yield- 
ing estimates, which are more efficient than that obtained from ordinary VAR model (Rajbhandari \& Zhang, 2017; Andrei \& Andrei (2015). In particular, this study uses a panel VECM as it considers a sample of stock exchanges spread across different countries in Asia. Panel VECM helps to model the existing heterogeneity across these countries in terms of the structure of stock exchanges, their price movements, their macroeconomic structure, regulatory intervention, etc. The use of a panel VECM rather than a time series VECM includes the usual advantage of panel estimation over time series estimation as pointed out by Baltagi (2001).

VECM is a linear representation of a stochastic data generation process. For the purpose of this study, which proposes to establish the dynamic relationship between the spot and futures markets across the indices, both the spot and future prices are considered endogenous and the following multivariate panel VECM is considered, which supposedly contains more information, more variability and more efficiency than pure time series data.

$$
\begin{aligned}
& \Delta \ln S p_{i t}=\mu_{1 i}+\alpha_{1} E C T_{i t-1}+ \\
& +\sum_{l=1}^{p} \beta_{11, l} \Delta \ln s p_{i t-l}+ \\
& +\sum_{l=1}^{p} \beta_{12, l} \Delta \ln f_{i t-l}+\varepsilon_{1 i t}, \\
& \Delta \ln F_{i t}=\mu_{2 i}+\alpha_{2} E C T_{i t-1}+ \\
& +\sum_{l=1}^{p} \beta_{21, l} \Delta \ln s p_{i t-l}+ \\
& +\sum_{l=1}^{p} \beta_{22, l} \Delta \ln f_{i t-l}+\varepsilon_{2 i t}, \\
& E C T_{i t-1}=\lambda\left(\ln s p_{i t-l}-\theta-\gamma \ln f_{i t-l}\right),
\end{aligned}
$$

where $\Delta$ is the first difference operator; $\ln S p$ and $\ln f$ represent the logarithmic transformation of spot prices and futures prices, respectively; $\mu_{k i}$ for $k=1,2,3 \ldots$ are the cross section (exchange/country in this study) specific fixed effects; $\alpha_{k}$ is the coefficient of the error correction term; $\beta_{k k, l}$ is the coefficient corresponding to the $l$-th lag of the endogenous variables, and $\varepsilon_{k, i t}$ are the idiosyncratic errors.
The first term $E C T_{i t-1}$ in equation (1) and (2) and as expressed in (3) is referred to as the error correction term. It represents the error correction mechanism through which price advances in spot and futures markets to attune in the long run. It designates the long-run association between spot and future prices and assists as a measure of deviation from equilibrium between $\Delta \ln S p_{i t}$ and $\Delta \ln$ $F_{i t}$. The statistical significance and the size of the coefficient corresponding to error correction term determines the inclination of each endogenous variable to converge back to its equilibrium level. Thus, this coefficient represents a critical parameter in the assessment of a Vector Error Correction Model. The remaining terms in the two equations control for lags and additional dynamics in $\Delta \ln$ $S p_{i t}$ and $\Delta \ln F_{i t}$. The ' $\beta$ ' coefficients corresponding to these terms capture the short-run effects.

The two standard procedures to follow prior to applying the VECM model to test for the causal relationship between the spot and the futures prices are the panel unit root test and the panel cointegration tests. Causality tests are very sensitive to the stationarity of the underlying series. Thus, any attempt to test causality between variables needs to be preceded by tests for stationarity. Accordingly, this study begins by conducting a panel unit root test for the two variables - spot prices and futures prices. The establishment of non-stationarity of variables needs to be followed up with the test for existence of cointegration between the variables. The Residual Cointegration test developed by Pedroni (1999, 2004), which allows for heterogeneity across individual panel members, is used for this cointegration test. Pedroni (2004) proposed seven different test statistics, which he classified as within dimension and between dimensions. The null hypothesis for each of these tests is that there is no cointegration between the variables in the individual panels.

\section{RESULTS AND DISCUSSION}

Table A2 (Appendix) displays the descriptive statistics of futures and spot markets for the countries. The average returns for all countries in the sample for both markets are positive, with Korea being an exception, and their standard deviation is close to 0.5. Additionally, skewness coefficients 
are negative for both markets, except for China. Kurtosis coefficients in all cases are around 2.5.

As discussed in the Methodology section, the empirical analysis begins with the two tests, namely Panel Unit Root and Panel cointegration. The results of the panel unit root tests reported in Table 1 are based on four tests - Levin, Lin, and Chu (LLC), Im, Pesaran, and Shin W-stat (IPS), Augmented Dickey FullerFisher (ADF-Fischer Chi-square), and PP-Fisher Chi-square (PP-Fisher). The results of all the four unit root tests clearly indicate that both variables are non-stationary at level but are stationary at first difference. Thus, both spot and futures prices are non-stationary and integrated with order 1, thereby the conditions for cointegration tests are met.

Table 1. Panel unit root test

Source: Based on authors' calculations.

\begin{tabular}{|c|c|c|c|c|}
\hline $\begin{array}{c}\text { Panel unit } \\
\text { root test } \\
\text { method }\end{array}$ & Insp & $\Delta$ Insp & Inf & $\Delta \operatorname{lnf}$ \\
\hline \multirow{2}{*}{ LLC } & -0.430 & $-109.4^{* * *}$ & -0.411 & $-107.4^{* * *}$ \\
\hline & $(0.33)$ & $(0.000)$ & $(0.340)$ & $(0.000)$ \\
\hline \multirow{2}{*}{ IPS } & -0.422 & $-105.7 * * *$ & -0.604 & $-106.4^{* * *}$ \\
\hline & $(0.336)$ & $(0.000)$ & $(0.273)$ & $(0.000)$ \\
\hline \multirow{2}{*}{ ADF-Fisher } & 15.02 & $1471.8^{* * *}$ & 16.14 & $1433.5^{* * *}$ \\
\hline & $(0.66)$ & $(0.000)$ & $(0.583)$ & $(0.000)$ \\
\hline \multirow{2}{*}{ PP-Fisher } & 14.85 & $165.79 * * *$ & 16.15 & $165.8^{* * *}$ \\
\hline & $(0.67)$ & $(0.000)$ & $(0.58)$ & $(0.000)$ \\
\hline
\end{tabular}

Note: $* * *$ denotes the $1 \%$ significance level. $\mathrm{P}$ values are in parentheses.

The results of the cointegration test with and without trend are reported in Table 2. All tests reject the null hypothesis of no cointegration, thereby providing evidence of the presence of cointegration between the futures and spot prices. The null hypothesis is that the variables are not cointegrated.

Table 2. Pedroni cointegration test

Source: Based on authors' calculations.

\begin{tabular}{l|c|c}
\hline \multicolumn{1}{c}{ Test } & Without trend & With trend \\
\hline & Within Dimension & \\
\hline Panel v-stat & $143.5^{* * *}$ & $113.92^{* * *}$ \\
\hdashline Panel rho-stat & $-1927.8^{* * *}$ & $-1664.85^{* * *}$ \\
\hline Panel PP-stat & $-127.12^{* * *}$ & $-147.1^{* * *}$ \\
\hline Panel ADF-stat & $-52.8^{* * *}$ & $-62.54^{* * *}$ \\
\hline & Between Dimension \\
\hline Group rho-stat & $-2281.7^{* * *}$ & $-1882.13^{* * *}$ \\
\hline Group PP-stat & $-153.7^{* * *}$ & $-165.7^{* * *}$ \\
\hline Group ADF-stat & $-69.02^{* * *}$ & $-79.966^{* * *}$ \\
\hline
\end{tabular}

Note: $* *$ denotes the $1 \%$ level of significance.
Once cointegration between the spot and futures prices is established, the panel VECM is run to examine the causal relationship between the variables. The proposed VECM is as represented in equation (1) and (2) in section 3. Running the VECM requires the initial determination of the optimal VAR lag length (q). This requires minimizing the Akaike Information Criterion (AIC), Bayesian Information Criterion, and the Hannan Quinn Criterion (HQC) for each bivariate VAR in levels. The present study assumes a maximum lag value of five. This value corresponds to the workweek and hence is reasonable for a model involving daily financial data (Nicolau \& Palomba, 2015). It is common knowledge that all the information criteria may or may not suggest the same lag length. When they do suggest the same lag length, the corresponding lag is automatically selected. In the case where these criteria suggest different lag length, the optimal lag length is selected by conducting the Ljung and Box (1978) (Ljung \& Box, 1978) test residuals for autocorrelation (Nicolau \& Palomba, 2015). For this study, it is conducted from order 1 to order 5 . In the case of the present panel data, all three criteria return the lag length of five and, hence, the study proceeds for the VECM with an optimal lag length of four (one less than the optimal VAR lag length) (Lütkepohl, 2005).

As per the model specification, the expected sign for the adjustment coefficients $\alpha_{1}$ and $\alpha_{2}$ corresponding to 'ECT' term in equation (1) and (2) are $[-,+]$. This suggests that both markets contribute to error correction. If both of these coefficients are statistically significant, it may be inferred that there exists substantial price interaction between the spot and futures market.

The lead and lag relationship between the two markets is analyzed based on the significance and sign of the coefficients $\alpha_{1}$ and $\alpha_{2}$. A market that leads the price discovery will have an 'alpha' coefficient, which is not statistically significant. For example, if only $\alpha_{1}$ is statistically significant and negative as expected, then the spot market adjusts to remove pricing errors and price discovery happens first in the futures market. Alternatively, if only $\alpha_{2}$ is significant and with the expected positive sign, the market for futures does the adjustment and the spot market is quicker in reflecting price changes. 
Table 3. Panel VECM results

Source: Based on author's calculations.

\begin{tabular}{l|c|c|c|c}
\hline $\begin{array}{c}\text { Independent } \\
\text { variable }\end{array}$ & \multicolumn{2}{|c|}{ Dependent variable } & Ratio of speed of adjustment & $\begin{array}{c}\text { Verdict on pattern of adjustment to } \\
\text { equilibrium and price discovery }\end{array}$ \\
\cline { 2 - 5 } & $\Delta \operatorname{lnSp}$ & $\Delta \operatorname{lnf}$ & $\left(\boldsymbol{\alpha}_{2} /\left(\boldsymbol{\alpha}_{2}-\boldsymbol{\alpha}_{1}\right)\right)$ & \\
\hline$\Delta \operatorname{lnSp}$ & - & $243.06^{* * *}$ & - & - \\
\hline$\Delta \operatorname{lnf}$ & $225.2^{* * *}$ & - & - & \\
$\mathrm{ECT}(-1)$ & $-0.0296^{* * *}$ & $0.068^{* * *}$ & $0.068 /(0.068+0.0296)=0.697$ & $\begin{array}{c}\text { Both markets adjust but the spot market } \\
\text { contributes more to price discovery }\end{array}$ \\
\hline
\end{tabular}

Note: $* *$ and $*$ denote $1 \%$ and $10 \%$ significance levels, respectively. The values in parentheses are the corresponding standard errors.

If these two coefficients are substantial with the expected signs, then the relative magnitude of the adjustment coefficients establishes the prominence of each market in the price innovation. Following the literature data of Palladini and Portes (2011) and Ammer and Cai (2011), each market's contribution to price discovery is estimated by the ratio of the speed of adjustment $\left(\alpha_{2} /\left(\alpha_{2}-\alpha_{1}\right)\right)$. This ratio is between 0 and 1 . A value closer to 1 implies that the spot market has a greater contribution to price discovery as compared to that by futures market, while in the case of relatively greater contribution by futures market the value is closer to 0 . Cases with value around $1 / 2$ fail to provide clear evidence on the lead lag relationship between the markets and both markets are said to contribute to price innovation.

The results of the panel VECM are presented in Table 3. Table 3 also reports the results of the Wald test, which is applied to check the short-run dynamics of the spot and futures markets.
The study further extends to examine if the Global Financial Crisis brought about any change in the nature of the long-run and short-run association between spot and futures prices. For this, the entire sample period is divided into three different sub-periods:

1. Pre-GFC period - from the very day futures started trading on the respective stock exchange to August 9, 2007;

2. GFC period - August 10, 2007 to November 31, 2009;

3. Post-GFC period - from December 1, 2009 to February 28, 2020.

After the usual procedures of conducting panel unit root tests, panel cointegration tests, the price variables in each of these periods are found to exhibit the same non-stationarity property and cointegrating relations as in the earlier entire sample

Table 4. VECM results for sub-periods

Source: Based on author's calculations.

\begin{tabular}{|c|c|c|c|c|c|}
\hline \multirow{2}{*}{ Period } & \multirow{2}{*}{$\begin{array}{c}\text { Independent } \\
\text { variable }\end{array}$} & \multicolumn{2}{|c|}{ Dependent variable } & \multirow{2}{*}{$\begin{array}{c}\begin{array}{c}\text { Ratio of speed of } \\
\text { adjustment }\end{array} \\
\left(\alpha_{2} /\left(\alpha_{2}-\alpha_{1}\right)\right)\end{array}$} & \multirow{2}{*}{$\begin{array}{c}\text { Verdict on pattern } \\
\text { of adjustment to } \\
\text { equilibrium and price } \\
\text { discovery }\end{array}$} \\
\hline & & $\Delta \operatorname{lnSp}$ & $\Delta \operatorname{lnf}$ & & \\
\hline \multirow{3}{*}{ Pre-GFC } & $\Delta \operatorname{lnSp}$ & - & $188.6 * * *$ & \multirow{3}{*}{$\begin{array}{c}0.054 /(0.054+0.034) \\
=0.61\end{array}$} & \multirow{3}{*}{$\begin{array}{c}\text { Both markets adjust but the } \\
\text { spot market contributes } \\
\text { more to price discovery }\end{array}$} \\
\hline & $\Delta \operatorname{lnf}$ & $162.03 * * *$ & - & & \\
\hline & $\mathrm{ECT}(-1)$ & $-0.034^{* * *}(0.012)$ & $0.054 * * *(0.013)$ & & \\
\hline \multirow{3}{*}{ GFC } & $\Delta \operatorname{lnSp}$ & - & 4.75 & \multirow{3}{*}{--} & \multirow{3}{*}{$\begin{array}{l}\text { The market for futures } \\
\text { adjusts and the spot market } \\
\text { leads the price discovery }\end{array}$} \\
\hline & $\Delta \operatorname{lnf}$ & $19.16^{* * *}$ & - & & \\
\hline & $\mathrm{ECT}(-1)$ & $0.027(0.05)$ & $0.196 * * *(0.003)$ & & \\
\hline \multirow{3}{*}{ Post- GFC } & $\Delta \operatorname{lnSp}$ & - & $49.3^{* * *}$ & \multirow{3}{*}{-} & \multirow{3}{*}{$\begin{array}{l}\text { The market for futures } \\
\text { adjusts and the spot market } \\
\text { leads the price discovery }\end{array}$} \\
\hline & $\Delta \operatorname{lnf}$ & $32.85^{* * *}$ & - & & \\
\hline & $\mathrm{ECT}(-1)$ & $-0.027(0.02)$ & $0.131 * * *(0.02)$ & & \\
\hline
\end{tabular}

Note: $* * *$ and $*$ denote $1 \%$ and $10 \%$ significance levels, respectively. The values in parentheses are the corresponding standard errors. 
model. Thus, once again, VECM is run, but this time there are three VECMs run for each of the sub-periods mentioned. An optimal lag length of four was used for the same reason as before. Table 4 summarizes the findings of these models.

To further explore whether the development status of economies had any bearing on the nature of the interaction between the spot and futures markets during the pre-crisis, post-crisis and crisis periods, three more sets of VECM models are run for each of the two sets of countries, for three sub-periods. Table 5 shows the trends in these two diverse sets of countries.

It is evident from Table 3 that adjustment coefficients or coefficients corresponding to the Error Correction Term (ECT (-1)) in both the spot and futures market equations have the expected sign and are statistically significant. This implies that both markets contribute to price discovery and when disequilibrium arises among markets then both markets adjust to restore equilibrium in the long run. The speed of adjustment by the futures market as indicated by the error correction coefficient is 6.8 per cent per day, while that of the spot market is 2.96 per cent per day. These respective speeds of adjustment by each market yield a value of 0.697 as the ratio of the speed of adjustment calculated in column 4 of Table 3 . This insinuates that the futures market adjusts more than does the spot market. Hence, price discovery is a two-way pattern, but predominantly it is directed by the spot market. Hence, the spot market contributes more to price innovation than does the market for futures. Chi-Square test values and the corresponding $\mathrm{p}$ values reported in Table 3 establish the existence of bidirectional causality among these markets in the short run.

Table 4 demonstrates that the estimates of the adjustment coefficients in both the spot and futures markets in the Pre-Crisis period are statistically significant with the expected set of signs. Thus, price adjustment is done by both markets but is overall directed by the spot market and adjusted more (at the rate of 5.4 per cent per day) by the futures market. This is similar to the dynamics

Table 5. VECM results for country groups in pre-GFC, GFC and post-GFC periods

\begin{tabular}{|c|c|c|c|c|c|}
\hline \multirow{2}{*}{ Country group } & \multirow{2}{*}{$\begin{array}{l}\text { Independent } \\
\text { variable }\end{array}$} & \multicolumn{2}{|c|}{ Dependent variable } & \multirow{2}{*}{$\begin{array}{c}\begin{array}{c}\text { Ratio of speed of } \\
\text { adjustment }\end{array} \\
\left(\alpha_{2} /\left(\alpha_{2}-\alpha_{1}\right)\right)\end{array}$} & \multirow{2}{*}{$\begin{array}{c}\text { Verdict on pattern of } \\
\text { adjustment to equilibrium } \\
\text { and price discovery }\end{array}$} \\
\hline & & $\Delta \operatorname{lnSp}$ & $\Delta \operatorname{lnf}$ & & \\
\hline \multicolumn{6}{|c|}{ Pre-GFC } \\
\hline \multirow{3}{*}{ Advanced } & $\Delta \operatorname{lnSp}$ & - & $112.7 * * *$ & \multirow{3}{*}{-} & \multirow{3}{*}{$\begin{array}{c}\text { The market for futures adjusts } \\
\text { and the spot market leads the } \\
\text { price discovery }\end{array}$} \\
\hline & $\Delta \operatorname{lnf}$ & $107.1^{* * *}$ & - & & \\
\hline & $\mathrm{ECT}(-1)$ & $-0.16(0.013)$ & $0.058 * * *(0.014)$ & & \\
\hline \multirow{3}{*}{$\begin{array}{l}\text { Emerging and } \\
\text { developing }\end{array}$} & $\Delta \operatorname{lnSp}$ & - & $162.2^{* * *}$ & \multirow{3}{*}{$\begin{array}{l}0.089 /(0.089+0.065) \\
=0.58\end{array}$} & \multirow{3}{*}{$\begin{array}{l}\text { Both markets adjust but the } \\
\text { spot market contributes more } \\
\text { to price discovery }\end{array}$} \\
\hline & $\Delta \operatorname{lnf}$ & $68.6^{* * *}$ & - & & \\
\hline & $\operatorname{ECT}(-1)$ & $-0.065 * * *(0.017)$ & $0.089 * * *(0.019)$ & & \\
\hline \multicolumn{6}{|c|}{ During GFC } \\
\hline \multirow{3}{*}{ Advanced } & $\Delta \operatorname{lnSp}$ & - & 6.45 & - & \multirow{3}{*}{$\begin{array}{c}\text { The market for futures adjusts } \\
\text { and the spot market leads the } \\
\text { price discovery }\end{array}$} \\
\hline & $\Delta \operatorname{lnf}$ & $18.39 * * *$ & - & - & \\
\hline & $\mathrm{ECT}(-1)$ & $0.017(0.08)$ & $0.209 * *(0.08)$ & - & \\
\hline \multirow{3}{*}{$\begin{array}{l}\text { Emerging and } \\
\text { developing }\end{array}$} & $\Delta \operatorname{lnSp}$ & - & $9.29 *$ & \multirow{3}{*}{-} & \multirow{3}{*}{$\begin{array}{c}\text { The market for futures adjusts } \\
\text { and the spot market leads the } \\
\text { price discovery }\end{array}$} \\
\hline & $\Delta \operatorname{lnf}$ & 3.29 & - & & \\
\hline & ECT $(-1)$ & $0.043(0.08)$ & $0.226 * *(0.226)$ & & \\
\hline \multicolumn{6}{|c|}{ Post-GFC } \\
\hline \multirow{3}{*}{ Advanced } & $\Delta \operatorname{lnSp}$ & - & 4.42 & \multirow{3}{*}{$\begin{array}{c}0.117 / \\
(0.117-0.07)=0.63\end{array}$} & \multirow{3}{*}{$\begin{array}{l}\text { Both markets adjust but the } \\
\text { spot market contributes more } \\
\text { to price discovery }\end{array}$} \\
\hline & $\Delta \operatorname{lnf}$ & $42.4^{* *}$ & - & & \\
\hline & ECT $(-1)$ & $-0.07 * *(0.036)$ & $0.117 * * *(0.036)$ & & \\
\hline \multirow{3}{*}{$\begin{array}{l}\text { Emerging and } \\
\text { developing }\end{array}$} & $\Delta \operatorname{lnSp}$ & - & $93.4^{* * *}$ & \multirow{3}{*}{-} & \multirow{3}{*}{$\begin{array}{c}\text { The market for futures adjusts } \\
\text { and the spot market leads the } \\
\text { price discovery }\end{array}$} \\
\hline & $\Delta \operatorname{lnf}$ & 7.5 & - & & \\
\hline & $\mathrm{ECT}(-1)$ & $-0.015(0.02)$ & $0.133^{* * *}(0.025)$ & & \\
\hline
\end{tabular}

Note: $* * *$ and $*$ denote $1 \%$ and $10 \%$ levels of significance, respectively. The values in parentheses are the corresponding standard errors. 
observed in the earlier model covering all periods. During the Post-GFC period, the estimates of the adjustment terms have the expected signs, but while $\alpha_{2}$ in the futures equation is significant, $\alpha_{1}$ in the spot market equation is not statistically significant, meaning that in this period, price innovation is entirely led by the spot market, and the futures market adjusts with a speed of 13.1 per cent per day.

During the GFC period, the spot market leads the price innovation process and the futures market adjusts, and there is no price interaction between the markets. However, in this period, the coefficient of $\alpha_{1}$ is positive, indicating that instead of correcting the disequilibrium, the spot market movements increase the disequilibrium. However, the error correcting effect of the futures market is way higher and hence the overall market is drawn back to equilibrium. Comparison of the speed of adjustment in the futures market across the three different period shows that the crisis results in considerable alteration of the effectiveness of the futures market in removing errors and restoring equilibrium. While in the pre-crisis period, the speed is 5.4 per cent, that in the crisis and post-crisis period rises to 19.6 per cent and 13.1 per cent, respectively. This behavior could be attributed to the increased preferences for stock trading over futures trading during the crisis period as the later exhibits higher volatility.

Wald test results, as demonstrated by the value and significance of the chi-square test statistic reported in Table 4, show that there is short-run bidirectional causality between spot and future prices during both the Pre-GFC and Post-GFC periods. However, during the GFC period, there is a unidirectional information flow from the futures market to the spot market.

Table 5 shows that there is no specific pattern that can sum up the average impact of the development status as far as long-run adjustment is concerned.
As in the earlier exercises involving all periods and three sub-periods for entire set of countries, in this case too, one pattern, which is consistently observed among both country groups and across all sub-periods, is that the spot market leads the price discovery, while the futures market adjusts. And as before, the spot market movements during the GFC period in both country groups add to the disequilibrium. But the strength of the error correction by the futures market helps to draw the system back towards equilibrium. Thus, as the results are invariably the same across these groups of countries, it can be concurred that the parameters distinguishing the development status do not have any bearing on the information spillover in these markets.

However, the development status of the countries does change in the short-run dynamics between the markets during the crisis period. While the advanced countries exhibit short-run unidirectional causality from the futures market to the spot market, in the case of developing economies, the direction of the information flow is reversed i.e., from the spot market to the futures market. The trend observed in advanced countries may be owing to the premise that the traders are able to gauge market sentiments more precisely owing to superior market quality and grabbing the advantage of the leverage effect, they consider taking more positions in the futures market, which eventually leads to higher market depth and better price discovery. The contrary situation observed in emerging markets may be ascribed to informed investors abstaining from taking positions in the futures market due to apprehension of higher volatility, which is usually experienced in times of uncertainty leading to lower market depth, eventually leading to complete erosion of their investments. Another reason may be attributed to the fact that market participants in developing economies are more risk averse, primarily due to lower amount of personal disposable income as compared to their counterparts in advanced economies.

\section{CONCLUSION}

The paper evaluates the information transmission between the futures and spot markets for nine major indices of nine advanced and emerging countries in Asia. The results for the entire sample period advocate that the spot market contributes more to price innovation. In the short run, a bidirectional causality 
is perceived. In the sub-periods, in the long run, identical occurrences were apparent, while in the short run, for both pre-GFC and post-GFC, a bidirectional causality subsists. However, in the crisis period, there runs a unidirectional causality from the futures market to the spot market. Plausible reasons why the spot market dominates the informational role may be due to excessive liquidity and high market depth in the spot market as compared to futures. Also, unlike the US where there are numerous spot markets and multiple derivatives markets, in Asia there are several spot markets, but there can only be one primary derivatives market, which may be a pertinent factor for the spot market leading the information dissemination. Moreover, informed traders are impetuous of speedy execution of large orders, which may not subsist in the futures market leading to the preferred choice of trading venue being the spot market. This phenomenon may also be attributed to more informed market participants taking larger positions in the spot market as compared to futures, which are more volatile and possess higher downside risk. The paper validates that in major Asian bourses, traders choose liquidity over leverage benefit and higher volatility. The study also highlights that the development status and the dynamics distinguishing the development status of countries has no particular bearing on the nature of interaction between the markets, except during the crisis period wherein a unidirectional causality from futures to spot in advance economies was observed and a contrary approach was witnessed in the emerging economies.

The paper adds a new dimension to the literature as the study captures the major indices in the Asian region, which is a considerable segment of Asian futures trading. The significant takeaway of this study is that global asset allocators may incorporate the spot market movements when developing their respective trading strategies to increase expected returns. The study also predicates the existence of index arbitrage opportunities in the developed and emerging economies of Asia. It empirically demonstrates that during the crisis period, market participants of advanced and developing nations may be more cautious while considering markets for investment decisions. Policy makers can develop strategies to integrate markets in order to increase market participation, which will eventually lead to more financial inclusion.

\section{AUTHOR CONTRIBUTIONS}

Conceptualization: Sangeeta Wats, Chandrima Sikdar.

Data curation: Sangeeta Wats, Chandrima Sikdar.

Formal analysis: Sangeeta Wats, Chandrima Sikdar.

Investigation: Sangeeta Wats, Chandrima Sikdar.

Methodology: Sangeeta Wats, Chandrima Sikdar.

Project administration: Sangeeta Wats, Chandrima Sikdar.

Resources: Sangeeta Wats, Chandrima Sikdar.

Software: Sangeeta Wats, Chandrima Sikdar.

Supervision: Sangeeta Wats, Chandrima Sikdar.

Validation: Sangeeta Wats, Chandrima Sikdar.

Visualization: Sangeeta Wats, Chandrima Sikdar.

Writing - original draft: Sangeeta Wats, Chandrima Sikdar.

Writing - review and editing: Sangeeta Wats, Chandrima Sikdar.

\section{REFERENCES}

1. Ahn, K., Yingyao, B., \& Sohn, S. (2018). Price discovery among SSE 50 Index-based spot, futures, and options markets. The Journal of Futures Markets, 39(12), 238-259.

2. Ammer, J., \& Cai, F. (2011). Sovereign CDS and bond pricing dynamics in emerging markets: Does the cheapest-todeliver option matter? Journal of International Financial Markets, Institutions and Money, 21(3), 369-387.

3. Andrei, D. M., \& Andrei, L. C. (2015). Vector error correction model in explaining the association of some macroeconomic variables in Romania. Procedia Economics and Finance, 22, 568-576. https://doi.org/10.1016/S22125671(15)00261-0 
4. Baltagi, B. H. (2001). Econometric Analysis of Panel Data (2nd ed.). Chichester: John Wiley \& Sons.

5. Brandt, M. W., Kavajecz, K. A., \& Underwood, S. E. (2007). Price discovery in the treasury futures market. The Journal of Futures Markets, 27(11), 1021-1051. http:// dx.doi.org/10.1002/fut.20275

6. Booth, G. G., So, R. W., \& Tse, Y. (1999). Price discovery in the German equity index derivatives markets. The Journal of Futures Markets, 19(6), 619-643. https:// doi.org/10.1002/(SICI)10969934(199909)19:6\%3C619::AIDFUT1\%3E3.0.CO;2-M

7. Chan, K. (1992). A further analysis of the lead-lag relationship between the cash markets and stock index futures markets. Review of Financial Studies, 5(1), 123-152. Retrieved from https://ideas.repec.org/a/ oup/rfinst/v5y1992i1p123-52.html

8. Chan, L., \& Lien, D. (2002). Measuring the impacts of cash settlement: A stochastic volatility approach. International Review of Economics and Finance, 11(3), 251-263.

9. Chen, Y. L., \& Tsai, W.C. (2017) Determinants of price discovery in the VIX futures markets. Journal of Empirical Finance, 43, 59-73. http://dx.doi.org/10.1016/j. jempfin.2017.05.002

10. Cheung, Y. W., \& Fung, H. G. (1997). Information flows between Eurodollar spot and futures markets. Multinational Finance Journal, 1(4), 255-271.

11. Choy, S. K., \& Zhang, H. (2010). Trading Costs and Price Discovery. Review of Quantitative Finance and Accounting, 34(1), 37-57.

12. Chuang, C. C. (2003). International Information Transmission between Stock Index Futures and Spot Markets: The Case of Futures Contracts Related to Taiwan Index. Journal of Management Science, 19, 51-78.

13. Dimpfl, T., Flad, M., \& Jung, R.C. (2017). Price discovery in agricultural commodity markets in the presence of futures speculation. Journal of Commodity Markets, 5, 50-62.
14. Entrop, O., Frijns, B. \& Seruset, M. (2020). The determinants of price discovery on bitcoin markets. The Journal of Futures Markets, 40(5), 816-837. https://doi.org/10.1002/ fut.22101

15. Fassas, A.P., \& Siriopoulos, C. (2019). Intraday price discovery and volatility spillovers in an emerging market. International Review of Economics \& Finance, 59, 336-346.

16. Fleming, J., Ostdiek, B., \& Whaley, R. E. (1996). Trading Costs and the relative rates of price discovery in stock, futures and options markets. The Journal of Futures Markets, 16(4), 353-387.

17. Hasbrouck, J. (1995). One security many markets: Determining the contribution to price discovery. Journal of Finance, 50(4), 11751199. Retrieved from https:// econpapers.repec.org/article/ blajfinan/v_3a50_3ay_3a1995_3ai 3a4_3ap_3a1175-99.htm

18. Hasbrouck, J. (2003). Intraday Price Formation in U.S. Equity Index Markets. The Journal of Finance, 58(6), 2375-2400.

19. Jacobs, H. (2016). Market maturity and mispricing. Journal of Financial Economics, 122(2), 270-287. https://doi.org/10.1016/j. jfineco.2016.01.030

20. Jong, D. F., \& Donders, M. W. M. (1998). Intraday leadlag relationship between the futures options and stock market. European Finance Review, 1, 337-359. https://doi. org/10.1023/A:1009765322522

21. Karabiyik, H., Narayan, P. K., Phan, D. H. B., \& Westerlund, J. (2018). Islamic spot and index futures markets: Where is the price discovery? Pacific-Basin Finance Journal, 52, 123-133. http://dx.doi.org/10.1016/j.pacfin.2017.04.003

22. Kavussanos, M., \& Nomikos, N. K. (2003). Price discovery causality and forecasting in the freight futures market. Review of Derivatives Research, 6(3), 203-230.

23. Kawaller, I. G., Koch, P. D., \& Koch, T. W. (1987). The temporal price relationship between
S\&P 500 futures and the S\&P 500 index. Journal of Finance, 42(5), 1309-1329. https://doi. org/10.2307/2328529

24. Kumar, K., \& Chaturvedula, C. (2013). Price leadership between spot and futures markets. Journal of Applied Finance \& Banking, 3(1), 93-107. Retrieved from https:// ideas.repec.org/a/spt/apfiba/ v3y2013i1f3_1_6.html

25. Lihara, Y., Kato, K., \& Tokunaga, T. (1996). Intraday return dynamics between the cash and the futures markets in Japan. The Journal of Futures Markets, 16(2), 147-162. https:// doi.org/10.1002/(SICI)10969934(199604)16:2\%3C147::AIDFUT2\%3E3.0.CO;2-K

26. Lin, C. B., Chou, R. K., \& Wang, G. H. (2018). Investor sentiment and price discovery: Evidence from the pricing dynamics between the futures and spot market. Journal of Banking and Finance, 90, 17-31.

27. Ljung, G. M., \& Box, G. E. P. (1978) On a Measure of Lack of Fit in Time Series Models. Biometrika, 65(2), 297-303. http://dx.doi. org/10.1093/biomet/65.2.297

28. Lütkephol, H. (2005). Structural vector autoregressive analysis for cointegrated variables (EUI Working Paper, ECO (2005/2)). Retrieved from https://core.ac.uk/ download/pdf/41100689.pdf

29. Min, J. H., \& Najand, M. (1999). A further investigation of lead lag relationship between the spot market and the stock index futures: Early evidence from Korea. The Journal of Futures Markets, 19(2), 217-232.

30. Newell, G. (2010). The effectiveness of A-REIT futures as a risk management strategy in theglobal financial crisis. Pacific Rim Property Research Journal, 16(3), 339-357. http://dx.doi.org/1 0.1080/14445921.2010.11104308

31. Nicolau, M., \& Palomba, G. (2015). Dynamic relationships between spot and futures prices. The case of energy and gold commodities. Resources Policy, 45, 130-143. https://doi.org/10.1016/j. resourpol.2015.04.004 
32. Palladini, G., \& Portes, R. (2011). Sovereign CDS and bond pricing dynamics in the Euro-area (Working Papers, 17586). National Bureau of Economic Research, Inc. (NBER). Retrieved from https:// econpapers.repec.org/paper/nbrnberwo/17586.htm

33. Pedroni, P. (1999). Critical values for cointegration tests in heterogeneous panels with multiple regressors. Oxford Bulletin of Economics and Statistics, 61(S1), 653-670. https://doi. org/10.1111/1468-0084.0610s1653

34. Pedroni, P. (2004). Panel cointegration: asymptotic and finite sample properties of pooled time series tests with an application to the PPP hypothesis. Econometric Theory, 20(3), 597625.

35. Pizzi, M. A., Economopoulous, A. J., \& O’Neill, H. M. (1998). An examination of the relationship between stock index cash and futures markets: A cointegration approach. The Journal of Futures Markets, 18(3), 297-305. http:// dx.doi.org/10.1002/(SICI)10969934(199805)18:3\%3C297::AIDFUT4\%3E3.0.CO;2-3

36. Quan, J. (1992). Two-step testing procedure for price discovery role of futures prices. The Journal of Futures Market, 12, 139-149.

37. Rajbhandari, A., \& Zhang, F. (2017). Does Energy Efficiency Promote Economic Growth? Evidence from a Multi-Country and Multi-Sector Panel Data Set (Working Paper, 8077). World Bank Policy Research.

38. Rajput, N., Kakkar, R., Batra, G., \& Gupta, M. (2012). Price discovery in Indian stock market: case of S\&P CNX Nifty index. Investment Management and Financial Innovations, 9(3), 120129. Retrieved from https://www. businessperspectives.org/index. $\mathrm{php} /$ component/zoo/?controlle

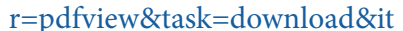
em_id $=4768$

39. Roope, M., \& Zurbruegg, R. (2002). The intraday price discovery process between the Singapore Exchange and Taiwan Futures Exchange. The Journal of
Futures Markets, 22(3), 219-240. https://doi.org/10.1002/fut.2215

40. Schlusche, B. (2009). Price formation in spot and futures markets: exchange traded funds vs. index futures. The Journal of Derivatives, 17(2), 26-40. https://doi.org/10.3905/ JOD.2009.17.2.026

41. Shrestha, K. (2014). Price Discovery in energy markets. Energy Economics, 45, 229233. Retrieved from https:// econpapers.repec.org/scripts/ redir.pf?u=https $\% 3 \mathrm{~A} \% 2 \mathrm{~F} \% 2 \mathrm{Fdoi}$. org\%2F10.1016\%252Fj.eneco.2014 06.007;h=repec:eee:eneeco:v:45:y: 2014:i:c:p:229-233

42. Shrestha, K., Subramaniam, R., \& Thiyagarajan, T. (2020). Price Discovery in Agricultural Markets. American Business Review, 23(1), 53-69.

43. Silvapulle, P., \& Moosa, I. M. (1999). The relationship between spot and futures prices: Evidence from the Crude Oil Market. The Journal of Futures Markets, 19(2), 175-193.

44. Telser, L. G. (1981). Why there are organized futures markets. The Journal of Law and Economics, 24(1), 1-22.

45. Theissen, E. (2012). Price discovery in spot and futures market: A Reconsideration. The European Journal of Finance, 18, 969-987. https://doi.org/10.1080/1 351847X.2011.601643

46. Turkington, J., \& Walsh, D. (1999). Price discovery and causality in the Australian share price index futures market. Australian Journal of Management, 24(2), 97-113. https://doi.org/10.1177\% 2F031289629902400201

47. Wahab, M., \& Lashgari, M. (1993). Price dynamics and error correction in stock index and stock index futures markets: A cointegration approach. The Journal of Futures Markets, 13(7), 711-742. https://doi.org/10.1002/ fut.3990130702

48. Wats, S., \& Misra, K.K. (2008). Price Discovery Efficiency of the Indian Futures Market: The Case Study of National Stock Exchange.
International Journal of Business Insights and Transformation, 2(1), 39-50.

49. Zou, L., \& Pinfold, J. (2001). Price functions between NZSE 10 index, index futures and TENZ: A cointegration approach and Error Correction Model. Working Paper Series, 1(10), 1-31.

50. Zhong, M., Darrat, A. F., \& Otero, R. (2004). Price discovery and volatility spillovers in index futures markets: Some evidence from Mexico. Journal of Banking and Finance, 28(12), 3037-3054. https://doi.org/10.1016/j.jbankfin.2004.05.001 


\section{APPENDIX A}

Table A1. List of indices considered for panel analysis

Source: http://www.imf.org./external/pubs/ft/weo/2020/01/weodata/groups.htm

\begin{tabular}{|c|c|c|c|c|c|}
\hline SI. No. & Country & Symbol & Index & $\begin{array}{c}\text { Futures Start } \\
\text { Date }\end{array}$ & $\begin{array}{c}\text { Category Emerging and Developing } \\
\text { or Advanced Economy }\end{array}$ \\
\hline 1 & Hong Kong & $\mathrm{HSI}$ & Hong Kong Hang Seng Index & $4 / 1 / 1992$ & Advanced \\
\hline 2 & Japan & NKY & NIKKEI 225 & $9 / 5 / 1988$ & Advanced \\
\hline 3 & Singapore & STI & Straits Times Index & $6 / 28 / 2000$ & Advanced \\
\hline 4 & South Korea & KOSPI2 & $\begin{array}{l}\text { Korea Stock Exchange KOSPI } \\
200 \text { Index }\end{array}$ & $5 / 3 / 1996$ & Advanced \\
\hline 5 & Taiwan & TWSE & $\begin{array}{c}\text { Taiwan Stock Exchange } \\
\text { Weighted Index }\end{array}$ & $7 / 21 / 1998$ & Advanced \\
\hline 6 & China & SHSZ300 & $\begin{array}{l}\text { Shanghai Shenzhen CSI } 300 \\
\text { Index }\end{array}$ & $4 / 16 / 2010$ & Emerging and Developing \\
\hline 7 & India & NIFTY & NSE Nifty 50 Index & $6 / 12 / 2000$ & Emerging and Developing \\
\hline 8 & Malaysia & FBMKLCl & FTSE Bursa Malaysia KLCI Index & $12 / 15 / 1995$ & Emerging and Developing \\
\hline 9 & Thailand & SET50 & Stock Exchange of Thailand & $4 / 28 / 2006$ & Emerging and Developing \\
\hline
\end{tabular}

The country classification is based on the IMF, World Economic Outlook, which splits the world into two main clusters: advanced economies and emerging and developing economies. "The distinguishing parameters between advanced and emerging and developing economies as defined by IMF are as follows:

- GDP.

- Inflation.

- GDP per capita in purchasing power parity terms.

- Fiscal data.

- Unemployment rates and employment growth.

- External sector statistics like Balance of Payments.

- Foreign trade volumes and prices."

Table A2. Summary statistics of return rates of futures and spot prices

Source: Based on authors' calculation.

\begin{tabular}{|c|c|c|c|c|c|c|c|c|c|}
\hline Statistics & China & Hong Kong & Japan & India & Korea & Malaysia & Singapore & Taiwan & Thailand \\
\hline \multicolumn{10}{|c|}{ Spot } \\
\hline Mean & 6.166 & 7.613 & 4.965 & 4.363 & -1.975 & 5.760 & 7.456 & 5.461 & 3.142 \\
\hline Maximum & 6.760 & 8.353 & 5.610 & 5.164 & -1.154 & 6.396 & 7.935 & 6.01 & 3.653 \\
\hline Minimum & 5.814 & 6.466 & 4.146 & 2.879 & -3.87 & 4.188 & 6.508 & 4.602 & 2.014 \\
\hline Std. Dev. & 0.189 & 0.421 & 0.293 & 0.663 & 0.618 & 0.437 & 0.398 & 0.289 & 0.382 \\
\hline Skewness & 0.248 & -0.383 & -0.307 & -0.841 & -0.781 & -0.559 & -0.785 & -0.522 & -0.882 \\
\hline Kurtosis & 2.603 & 2.181 & 2.562 & 2.313 & 2.608 & 2.341 & 2.176 & 2.568 & 2.89 \\
\hline \multicolumn{10}{|c|}{ Futures } \\
\hline Mean & 6.164 & 7.612 & 4.996 & 4.363 & -1.974 & 5.759 & 7.47 & 5.459 & 3.142 \\
\hline Maximum & 6.758 & 8.353 & 5.633 & 5.165 & -1.151 & 6.394 & 7.933 & 6.10 & 3.653 \\
\hline Minimum & 5.815 & 6.481 & 4.149 & 2.88 & -3.922 & 4.234 & 6.534 & 4.596 & 1.994 \\
\hline Std. Dev. & 0.188 & 0.421 & 0.295 & 0.664 & 0.621 & 0.436 & 0.392 & 0.290 & 0.384 \\
\hline Skewness & 0.264 & -0.387 & -0.296 & -0.839 & -0.796 & -0.550 & -0.795 & -0.535 & -0.894 \\
\hline Kurtosis & 2.672 & 2.191 & 2.556 & 2.309 & 2.662 & 2.325 & 2.192 & 2.599 & 2.943 \\
\hline
\end{tabular}

